\title{
Exigências térmicas e filocrono de Dipteryx alata sob níveis de sombreamento na transição Cerrado-Amazônia
}

Thermal requirements and filocron of Dipteryx alata under shading levels in the CerradoAmazon transtition

\author{
D. R. Borella ${ }^{1 *}$; A. P. de Souza ${ }^{1,2}$; A. C. da Silva 2 ; R. T. A. Felipe ${ }^{3}$; \\ K. N. C. Silva ${ }^{4}$ J. H. G. de Souza ${ }^{4}$ \\ ${ }_{1}^{1}$ Programa de Pós-Graduação em Física Ambiental, Instituto de Física, Universidade Federal de Mato Grosso, \\ 78060-900, Cuiabá, MT, Brasil \\ ${ }^{2}$ Instituto de Ciências Agrárias e Ambientais, Universidade Federal de Mato Grosso, 78550-728, Sinop, MT, Brasil \\ ${ }^{3}$ Instituto de Ciências Naturais, Humanas e Sociais, Universidade Federal de Mato Grosso, 78550-728, Sinop, MT, \\ Brasil \\ ${ }^{4}$ Curso de Engenharia Florestal, Instituto de Ciências Agrárias e Ambientais, Universidade Federal de Mato Grosso, \\ 78550-728, Sinop, MT, Brasil \\ *drborella@gmail.com
}

(Recebido em 25 de novembro de 2019; aceito em 29 de maio de 2020)

\begin{abstract}
Objetivou-se avaliar se níveis de sombreamento afetam as exigências térmicas e o filocrono de mudas de Dipteryx alata, na estação seca da região de transição Cerrado-Amazônia. Foram empregadas telas poliefinas pretas $(35 ; 50 ; 65$ e $80 \%$ de sombreamento) e telas coloridas (termorefletora, vermelha, azul e verde, ambas com 50\% de sombreamento) e pleno sol (referência). As temperaturas basais foram obtidas por regressões polinomiais entre temperatura do ar no interior dos telados de sombreamento e área foliar total por muda. $\mathrm{O}$ filocrono foi obtido por ajustes polinomiais entre o número médio de folhas e de folíolos com a soma térmica acumulada. A temperatura basal máxima e mínima de Dipteryx alata foi de 39,81 e $10,10^{\circ} \mathrm{C}$. Não ocorreram diferenças significativas no número de folhas e folíolos, contudo, o incremento do nível de sombreamento aumentou a necessidade de energia térmica para o surgimento de folhas e folíolos $\left(238,96^{\circ} \mathrm{C}\right.$ dia $^{-1}$. folha ${ }^{-1} \mathrm{e}$ $28,40^{\circ} \mathrm{C}$.dia ${ }^{-1}$.folíolo $\left.{ }^{-1}\right)$ em relação ao pleno sol $\left(166,44^{\circ} \mathrm{C} \cdot \mathrm{dia}^{-1}\right.$.folha ${ }^{-1}$ e $17,10^{\circ} \mathrm{C}$ dia $^{-1}$.folíolo $\left.{ }^{-1}\right)$. Na tela de sombreamento vermelha (50\%) ocorreram menores valores de filocrono para a emissão de uma nova folha $\left(147,90^{\circ} \mathrm{C} \cdot \mathrm{dia}^{-1}\right.$.folha $\left.{ }^{-1}\right)$ e de folíolo $\left(20,39^{\circ} \mathrm{C} \cdot \mathrm{dia}^{-1}\right.$.folíolo $\left.{ }^{-1}\right)$. O surgimento e a expansão foliar de mudas de Dipteryx alata depende da dinâmica microclimática quanti-qualitativa da radiação solar incidente, contudo, a espécie apresenta forte adaptabilidade fenotípica a diferentes condições ambientais. Para aumentar a área foliar e consequentemente a atividade fotossintética da planta, recomenda-se a produção das mudas de Dipteryx alata sob sombreamento, exceto sob a tela azul.

Palavras-chave: Baruzeiro, Emissão de folhas, Temperatura basal.
\end{abstract}

The objective was to evaluate if levels of shading affect the thermal requirements and phyllochron of seedlings Dipteryx alata in the dry season of a transition region of Cerrado-Amazonia black polyolefin screens (35; 50, 65 and 80\% of shading) and colorful (thermophobe, red, blue and green, both with 50\% shading), and full sun (reference) were used for shading. The basal temperatures were determined by polynomial regressions between air temperature in shaded greenhouses and total leaf area by seedling. The phyllochron was obtained by polynomial adjustments between the mean number of leaves and leaflets with the accumulated thermal sum. The maximum and minimum basal temperature of Dipteryx alata was 39.81 and $10.10^{\circ} \mathrm{C}$. There were no significant differences in the number of leaves and leaflets, however, the increase in shading increased the need for thermal energy for the appearance of leaves and leaflets $\left(238.96^{\circ} \mathrm{C}^{\circ}\right.$ day $^{-}$ ${ }^{1}$.leaf ${ }^{-1}$ and $28.40^{\circ} \mathrm{C}$. day ${ }^{-1}$. leaflet $\left.{ }^{-1}\right)$ relative to the full sun $\left(166.44^{\circ} \mathrm{C}\right.$ day $^{-1}$. leaf $^{-1}$ and $17.10^{\circ} \mathrm{C}^{- \text {day }^{-1}}$. leaflet $^{-}$ $\left.{ }^{1}\right)$. In the red shading screen $(50 \%)$, lower phyllochron was required for leaf emission $\left(147.90^{\circ} \mathrm{C}^{- \text {day }^{-1}} \cdot \mathrm{leaf}^{-1}\right)$ and leaflet $\left(20.39^{\circ} \mathrm{C}_{\text {.day }}{ }^{-1}\right.$.leaflet $\left.{ }^{-1}\right)$. The emergence and expansion of leaf of Dipteryx alata seedlings depends on the quantitative-qualitative microclimatic dynamics of incident solar radiation, however, the species presents strong adaptability to different environmental conditions. To increase the leaf area and consequently the photosynthetic activity of the plant, it is recommended the production of the Dipteryx alata seedlings under shading, except under the blue screen.

Keywords: Baruzeiro; Emission of leaves, Basal temperature. 


\section{INTRODUÇÃO}

O baruzeiro (Dipteryx alata Vogel, Fabaceae) é uma planta arbórea de clima tropical e compõe a vegetação nativa do Cerrado brasileiro strictu sensu e as áreas de transição Cerrado-Amazônia. $\mathrm{Na}$ sucessão ecológica, essa espécie é considerada como secundária tardia, desenvolvendo-se em frações de sombreamento no sub-bosque da floresta [1], com boa adaptação à sazonalidade climática e variabilidade genética quanto a sua origem [2].

Dipteryx alata apresenta características desejadas nos cenários socioeconômico e ambiental, pois produz sementes oleaginosas comestíveis com elevados teores de proteínas, lipídios e minerais de potencial nutritivo [3] e bioativos consideráveis para a suplementação humana [4]. Além disso, ocorre rápida germinação das sementes e crescimento da muda [5], possibilitando a sua inserção em plantios de recuperação e restauração de áreas degradadas, sistemas produtivos, paisagismo, sombreamento de pastagem, quebra-ventos e como fixadora de nitrogênio no solo [1].

$\mathrm{O}$ crescimento, desenvolvimento e produtividade das plantas dependem das interações entre os fatores ambientais (solo/substrato e microclima) e os fatores de controle intra e intercelular, que correspondem ao potencial genético e aos hormônios bioquímicos vegetais, respectivamente. No âmbito microclimático, a radiação solar e suas influências nos fluxos de calor latente (evapotranspiração) e calor sensível (temperatura do ar) é um elemento essencial para o desenvolvimento vegetativo e reprodutivo, uma vez que regulam os processos bioquímicos, fisiológicos e morfogênicos das plantas [20, 30].

Em geral, os efeitos da temperatura do ar associados à radiação solar, em condições de estresse térmico, resultam em alterações significativas na temperatura foliar, no funcionamento dos complexos enzimáticos, reações químicas, na desestabilização de membranas e proteínas, no potencial hídrico das células, na fixação de $\mathrm{CO}_{2}$, acúmulo e partição de matéria seca durante a fotossíntese [6] e na taxa de emissão de folhas [7].

As plantas acumulam diariamente uma quantidade de energia que pode ser dada pela soma térmica acumulada (STA), perfazendo na energia disponível para a realização de seus processos metabólicos, dentro de faixas ótimas de temperatura, compreendidas por sua vez, acima da condição mínima (temperatura basal inferior) e abaixo da condição máxima (temperatura basal superior) de energia (temperatura) que limitaria as taxas de desenvolvimento da planta. Dentre essas taxas, a de emissão de folhas pode ser obtida com base nesse acúmulo de energia térmica e na sua determinação, utiliza-se o conceito de filocrono dado como o intervalo de tempo entre o aparecimento de duas folhas sucessivas na haste principal da planta, expressa em ${ }^{\circ}$ C.dia.folha ${ }^{-1}[8$, $9,10]$.

Diante do cenário atual de mudanças climáticas com previsões de aumento expressivo na temperatura do ar média global, o crescimento e o desenvolvimento das plantas, juntamente com o rendimento das culturas, poderão ser substancialmente afetados, gerando a necessidade de desenvolvimento de estratégias de adaptação das espécies [11]. Associado a isso, tem-se ainda a necessidade de estudos ecofisiológicos de espécies florestais nas fases iniciais de desenvolvimento (mudas) $[5,9,12]$ para obtenção de indivíduos mais vigorosos e adaptados para inserção nos sistemas produtivos.

Dessa forma, o conhecimento das necessidades térmicas das plantas pode contribuir para o planejamento e manejo adequado na implementação de sistemas produtivos com espécies mais adaptadas à sazonalidade climática do local, de modo a aumentar a qualidade e produtividade da atividade econômica exercida. Neste contexto, objetivou-se avaliar se níveis de sombreamento afetam as exigências térmicas e o filocrono de mudas de Dipteryx alata durante a estação seca da região de Transição Cerrado-Amazônia do estado de Mato Grosso.

\section{MATERIAL E MÉTODOS}

\subsection{Caracterização do local e instalações}

O experimento foi conduzido entre 04/06 a 07/10/2017 (125 dias), em Sinop-MT (11 ${ }^{\circ} 51^{\prime} 50 " S$; $55^{\circ} 29^{\prime} 08^{\prime \prime} \mathrm{W}, 384 \mathrm{~m}$ ) situado na região de transição Cerrado-Amazônia. O clima da região, segundo a classificação de Köppen é o tipo Aw (tropical quente e úmido), com duas estações hídricas bem 
definidas: chuvosa (outubro a abril) e seca (maio a setembro), e com temperaturas médias mensais variando de 24,0 a $27,0^{\circ} \mathrm{C}$, e precipitações anuais de $1970,0 \mathrm{~mm}$ [13].

As mudas de Dipteryx alata foram cultivadas em viveiros suspensos, alinhados no sentido LesteOeste, com dimensões de 3,0 x 1,0 x 1,0 m (comprimento, largura e altura) e a 1,0 m acima do solo. Esses módulos experimentais apresentavam coberturas superiores, frontais e laterais de telas poliefinas agrícolas, nas cores pretas (indicações comerciais de sombreamento de 35,0; 50,0; 65,0 e $80,0 \%$ ) e coloridas (termorefletora - aluminet $\AA$; vermelha e azul - chromatinet ${ }^{\circledR}$; verde frontinet ${ }^{\circledR}$, ambas comerciais com $50,0 \%$ de sombreamento), além da condição de pleno sol (referência).

Na condição de pleno sol, as variáveis meteorológicas (temperatura do ar, umidade relativa do ar e velocidade do vento) foram monitoradas por uma estação meteorológica automática Instrutemp modelo ITWH-1080, distante $20 \mathrm{~m}$ da área experimental, com armazenamento dos dados a cada 30 min; também foram realizadas medidas convencionais de rotina da insolação (heliógrafo CampbellStokes) e da altura pluviométrica (pluviômetro Ville de Paris). A radiação global foi obtida com base na insolação, com coeficientes lineares (a) e angulares (b) calibrados regionalmente na escala mensal [14].

Nas telas de sombreamento, o monitoramento micrometeorológico da temperatura e umidade relativa do ar ocorreu com intervalos de 30 minutos e foi realizado com termo-higrômetros com datalogger Instrutemp modelo HT 4000 ICEL, instalados a 1,50 $\mathrm{m}$ de altura, centralizado no interior de cada viveiro experimental.

A atenuação da radiação solar nas telas poliefinas de sombreamento foi determinada a partir de medidas pontuais da radiação global $\left(\mathrm{H}_{\mathrm{G}}\right)$, radiação fotossinteticamente ativa $\left(\mathrm{H}_{\mathrm{PAR}}\right)$ e da luminância (Lux) com o auxílio de piranômetros (MP-200; MQ-200 - Instrutherm) e luxímetros (LD-200 - Instrutherm), respectivamente. Esses sensores foram fixados em uma plataforma metálica, mantida em nível, a $1,50 \mathrm{~m}$ no interior do viveiro e a $0,50 \mathrm{~m}$ acima do viveiro. As leituras foram realizadas quinzenalmente, entre junho e outubro, das 08 às $11 \mathrm{~h}$ (horário solar local), no exterior (acima) e interior (dentro) dos viveiros experimentais para a determinação da atenuação e da transmissividade, dadas pela razão entre a leitura da variável no interior da tela de sombreamento e a leitura da variável acima (exterior) da tela de sombreamento, cujos valores estão descritos na Tabela 1.

Tabela 1: Percentual de transmissividade (média \pm desvio) da radiação global, radiação fotossinteticamente ativa (PAR) e luminância, em diferentes telas de sombreamento com relação ao pleno sol, Sinop, MT, 2017. Fonte: Autores.

\begin{tabular}{cccc}
\hline Tela de sombreamento & Radiação Global & Radiação PAR & Luminância \\
\hline Preta 35\% & $54,72 \pm 8,62$ & $53,25 \pm 6,42$ & $51,67 \pm 6,39$ \\
Preta 50\% & $45,91 \pm 5,80$ & $43,27 \pm 7,19$ & $43,36 \pm 4,51$ \\
Preta 65\% & $31,75 \pm 8,40$ & $33,34 \pm 5,39$ & $29,81 \pm 3,81$ \\
Preta 80\% & $16,70 \pm 1,71$ & $15,49 \pm 3,00$ & $15,12 \pm 2,88$ \\
Termorefletora 50\% & $32,51 \pm 6,33$ & $35,25 \pm 4,67$ & $33,67 \pm 2,60$ \\
Vermelha 50\% & $47,00 \pm 6,99$ & $30,95 \pm 4,08$ & $27,99 \pm 4,93$ \\
Azul 50\% & $44,35 \pm 3,25$ & $37,09 \pm 5,42$ & $33,17 \pm 2,96$ \\
Verde 50\% & $39,35 \pm 5,53$ & $28,74 \pm 2,97$ & $29,72 \pm 2,66$ \\
\hline
\end{tabular}

\subsection{Produção e manejo das mudas}

Os frutos de Dipteryx alata coletados entre agosto e setembro de 2016 de matrizes localizadas em Rondonópolis-MT ( $16^{\circ} 28^{\prime} 03^{\prime}$ 'S, 54 $38^{\circ}$ '49”'W e altitude de $287 \mathrm{~m}$ ) foram armazenados em saco de ráfia em ambiente laboratorial por oito meses. Período longo de pós-maturação das sementes de Dipteryx alata dentro do fruto é necessário para uniformizar a produção das mudas com vigor e qualidade [15]. Também foi verificado que longo período de armazenamento dessas sementes à temperatura ambiente não afetou o processo germinativo [16], corroborando com o observado no presente estudo.

As sementes passaram por assepsia em solução de Hipoclorito de Sódio $(\mathrm{NaClO})$ 2,0\% por 5 min, e pulverizadas com solução do fungicida Protreat ${ }^{\circledR} 2 \%$ durante a germinação. A germinação 
das sementes ocorreu por 14 dias em câmara de germinação sob temperatura de $30^{\circ} \mathrm{C}$ e fotoperíodo de $12 \mathrm{~h}$, sendo que as sementes foram envolvidas em Papel Germitest ${ }^{\circledR}$ umedecido com água destilada dentro de bandejas plásticas. Foram consideradas sementes germinadas aquelas com emissão de radícula com $2 \mathrm{~mm}$ ou mais.

Após 14 dias, as plântulas foram transplantadas para tubetes de polietileno de $820 \mathrm{~cm}^{3}$ contendo substrato formulado com a mistura de 50,0\% de substrato comercial (material orgânico), $10,0 \%$ de casca de arroz carbonizada e 40,0\% de solo de floresta nativa (Latossolo Vermelho-Amarelo distrófico). A adubação química usada foi de $40 ; 380$ e 80 g de $\mathrm{N}, \mathrm{P}_{2} \mathrm{O}_{5}$ e $\mathrm{K}_{2} \mathrm{O}$, por $\mathrm{m}^{3}$ de solo, nas formas de uréia, superfosfato simples e cloreto de potássio, respectivamente. As mudas permaneceram sob tela preta de $50 \%$ de sombreamento por 30 dias, visando a aclimatação e uniformidade; posteriormente à emissão da terceira folha composta completamente expandida, distribuiu-se as mudas nos tratamentos para início das avaliações.

Com base nas medidas meteorológicas a pleno sol, a evapotranspiração de referência $\left(\mathrm{ET}_{0}\right)$ diária foi obtida pelo método de Penman-Monteith FAO-56 [17], considerando-se nesse caso, as variáveis do modelo para regiões de clima úmido. A irrigação das mudas foi realizada pelo sistema de lisimetria por capilaridade formado por 36 lisímetros, sendo quatro repetições por tratamento (telas de sombreamento e a pleno sol). A reposição da água evapotranspirada pelas mudas em cada lisímetro de capilaridade foi realizada manualmente todos os dias para manutenção do nível de referência.

\subsection{Análise de crescimento e soma térmica}

A análise de crescimento não destrutiva das mudas, foi realizada quinzenalmente, perfazendo nove avaliações, nas quais foram avaliadas nove mudas por repetição (quatro repetições por tratamento); após 125 dias após transplantio (DAT) realizou-se a análise de crescimento destrutiva. Em todas as avaliações foram determinadas as variáveis morfométricas de crescimento das mudas: altura da muda em $\mathrm{cm}(\mathrm{H})$, diâmetro do coleto em $\mathrm{mm}$ (DC), número de folhas (NF) e de folíolos (NFO) por muda; na análise de crescimento destrutiva, obteve-se ainda a área foliar da muda em $\mathrm{cm}^{2}$ (AFM) obtida com medidor fotoelétrico LI-3100C e as partições de massa seca.

O desenvolvimento das mudas foi analisado considerando a soma térmica acumulada (grausdias acumulados - GDA), permitindo assim, aplicações independentemente das condições climáticas do local de cultivo. Para tanto, a temperatura basal superior - TB $\left(\mathrm{em}^{\circ} \mathrm{C}\right)$ e temperatura basal inferior - $\mathrm{Tb}\left(\mathrm{em}^{\circ} \mathrm{C}\right)$ das mudas de Dipteryx alata, foram obtidas por regressões polinomiais entre a temperatura máxima e mínima do ar (variáveis independentes) ao longo de todo o período experimental, tendo a área foliar média total por muda (obtida aos 125 DAT) como variável dependente [9]. As somas térmicas acumuladas (STA) foram determinadas conforme metodologia de Ometto [18].

O filocrono $\left({ }^{\circ} \mathrm{C}\right.$.dia.folha $\left.{ }^{-1}\right)$ foi obtido a partir de ajuste de regressões polinomiais cúbicas $(\mathrm{Y}=$ $\mathrm{A} 0+\mathrm{A} 1 \mathrm{x}+\mathrm{A} 2 \mathrm{x}^{2}+\mathrm{A} 3 \mathrm{x}^{3}$ ), considerando o número médio de folhas e de folíolos (variável dependente) com a soma térmica acumulada (variável independente).

\subsection{Análise estatística}

As análises estatísticas foram distribuídas em dois agrupamentos: i) nível quantitativo de sombreamento, visando avaliar o efeito do aumento do nível de sombreamento (pleno sol e telas poliefinas pretas de 45,3; 54,1; 68,3 e 83,3\% de sombreamento); ii) nível qualitativo de sombreamento, visando avaliar o efeito espectral da radiação solar (pleno sol, tela poliefina preta, tela termorefletora e telas poliefinas coloridas, com 50,0\% de sombreamento). Os dados foram submetidos ao teste de normalidade e posteriormente à análise de variância e, quando significativas, as médias foram comparadas pelo teste de Tukey a $5 \%$ de probabilidade. 


\section{RESULTADOS E DISCUSSÃO}

\subsection{Caracterização microclimática}

O aumento no nível do sombreamento, não influenciou na sazonalidade média diária da temperatura e da umidade relativa do ar, independentemente da condição de sombreamento (Figuras 1-3). Durante o período experimental, todavia, o nível de sombreamento acarretou na diminuição da radiação solar global total diária incidente nas telas poliefinas, com maior intensidade nas telas pretas (Figura 1A) quando comparado com as telas coloridas (Figura 1B). Na condição de pleno sol, foram observadas variações de $\mathrm{H}_{\mathrm{G}}$ entre 10,18 e $24,96 \mathrm{MJ} \mathrm{m}^{-2} \mathrm{dia}^{-1}$, decorrentes das flutuações atmosféricas de vapor d'água e aerossóis [19], que por sua vez, interferem na insolação e evapotranspiração de referência (Figuras $1 \mathrm{C}$ e $1 \mathrm{D}$ ). No final do experimento ocorreram precipitações acumuladas de 38,75 mm (Figura 1D). Nas telas de sombreamento, o efeito das flutuações atmosféricas foi minimizado, indicado pela menor oscilação da $\mathrm{H}_{\mathrm{G}}$ na tela poliefina preta de $83,3 \%$ de sombreamento, entre 1,70 a 4,17 $\mathrm{MJ} \mathrm{m}^{-2}$ dia $^{-1}$ (Figura $1 \mathrm{C})$.

A.
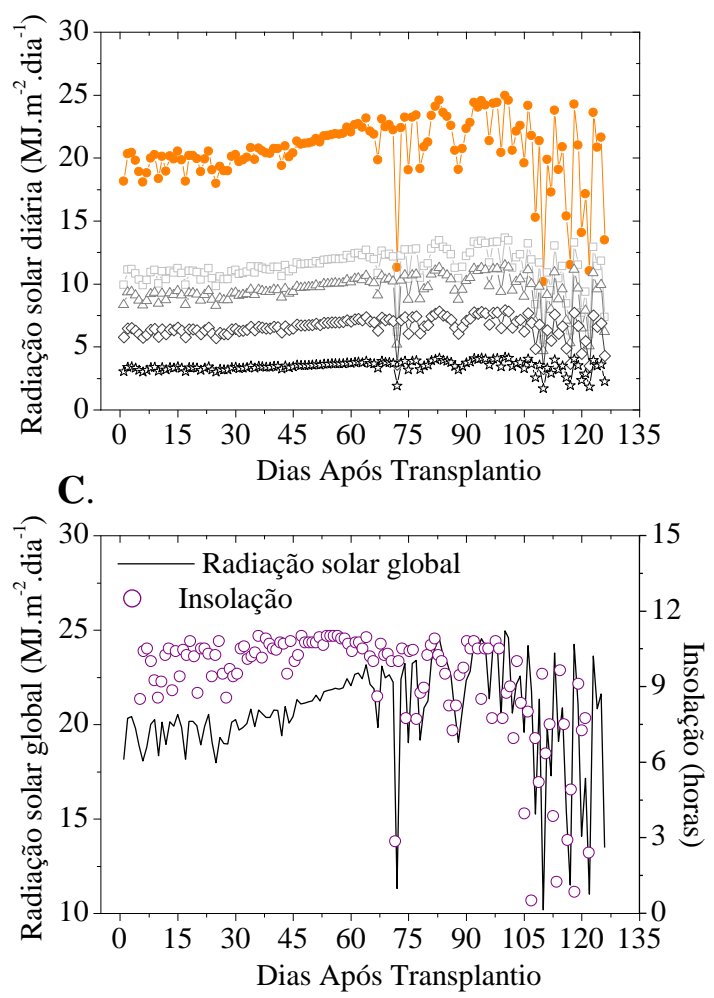

B.

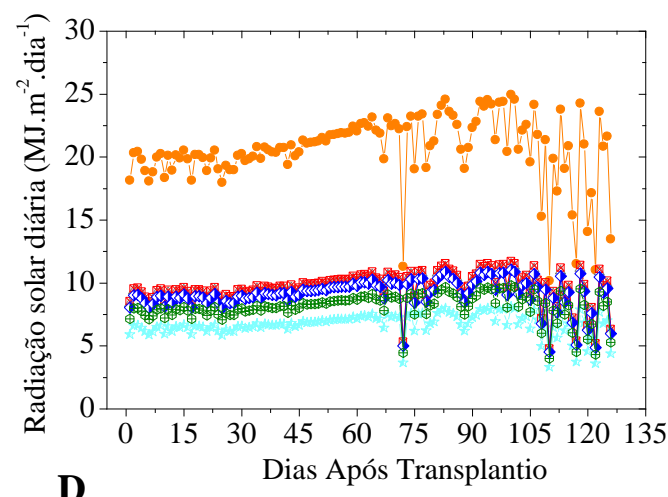

D.

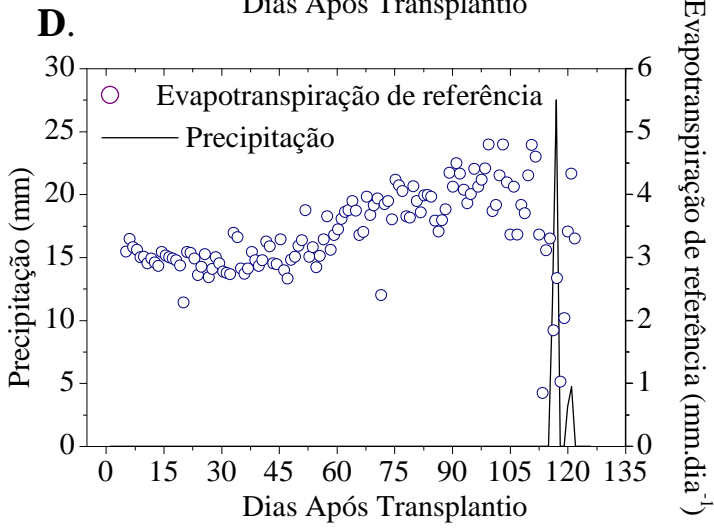

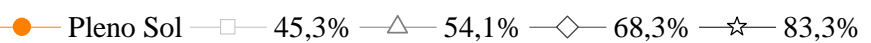

Termorefletora 50,0\%-₫ Vermelha 50,0\%-ه Azul 50,0\%-ゅ Verde 50,0\%

Figura 1: Valores médios diários da radiação solar global em viveiros com diferentes telas de sombreamento pretas (A) e coloridas (B) e médias diárias na condição de pleno sol, da insolação e radiação global (C), precipitação e evapotranspiração de referência (D), entre 04/06 a 07/10/2017 (0 e 125 DAT), em Sinop-MT.

Quanto às telas coloridas, a tela vermelha $\left(4,78\right.$ a $11,73 \mathrm{MJ} \mathrm{m}^{-2}$ dia $\left.^{-1}\right)$ e a tela termorefletora (3,31 a 8,11 MJ m $\left.\mathrm{dia}^{-1}\right)$ permitiram maior e menor incidência da $\mathrm{H}_{\mathrm{G}}$, respectivamente, sendo esse padrão condizente com os valores médios da transmissividade da $\mathrm{H}_{\mathrm{G}}$ encontrados para essas telas em relação à condição pleno sol (Tabela 1).

Houve dinâmica semelhante na sazonalidade da radiação global e da temperatura do ar (máximas, médias e mínimas) nas telas poliefinas e a pleno sol. Foram registrados valores de temperatura do ar máxima entre $40,1^{\circ} \mathrm{C}$ na condição de pleno sol e $50,2^{\circ} \mathrm{C}$ na tela termorefletora, entre agosto e setembro de 2017. No mesmo período observou-se valores de temperatura do ar 
média entre $27,7^{\circ} \mathrm{C}$ na tela preta de $68,3 \%$ de sombreamento e $28,9^{\circ} \mathrm{C}$ na tela vermelha (Figura 2 ). Na metade do mês de julho houve uma redução da temperatura do ar, em função do deslocamento de uma massa de ar fria que atingiu a região Centro-Oeste, ocasionando o registro da temperatura do ar mínima de $9,1^{\circ} \mathrm{C}$ na tela azul e $9,8^{\circ} \mathrm{C}$ na tela preta de $68,3 \%$ de sombreamento (Figura 2).

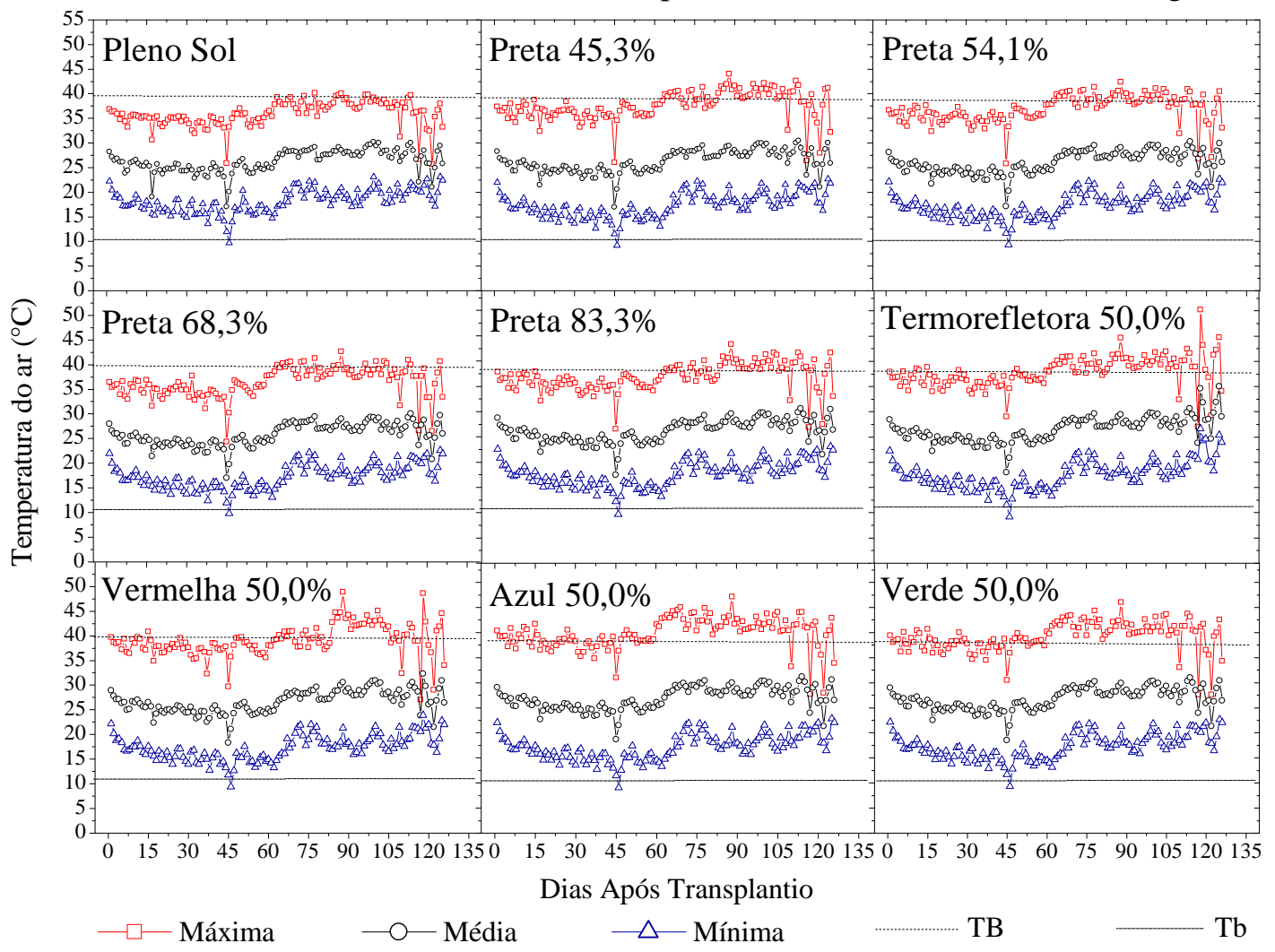

Figura 2: Temperatura do ar máxima, média e mínima diária, no interior de viveiros florestais suspensos com diferentes telas de sombreamento, entre 04/06 a 07/10/2017 (0 e 125 DAT), em Sinop-MT.

Na evolução média mensal diurna (07 às 18 h) e noturna (19 às 06 h), baseada no horário solar local, observou-se maiores valores de temperatura do ar no período diurno, independentemente da condição de sombreamento (Figura 3). Na condição de pleno sol, as temperaturas máximas diárias ocorreram por volta das $14 \mathrm{~h}$ e as mínimas às $06 \mathrm{~h}$ (horário solar local), enquanto que nas telas pretas com níveis crescentes de sombreamento e nas telas coloridas (espectrais), ocorreu uma antecipação da temperatura máxima diária e uma sincronização com o momento de maior incidência de $\mathrm{H}_{\mathrm{G}}$ (passagem meridional) em todos os meses (Figura 3).

Maiores amplitudes da temperatura do ar média horária ocorreram em agosto e setembro, com destaque para a condição de pleno sol $\left(16,8^{\circ} \mathrm{C}\right)$, telas pretas $\left(19,5^{\circ} \mathrm{C}\right)$ e nas telas termorefletora $\left(20,3^{\circ} \mathrm{C}\right)$, vermelha $\left(20,9^{\circ} \mathrm{C}\right)$, azul $\left(23,2^{\circ} \mathrm{C}\right)$ e verde $\left(22,3^{\circ} \mathrm{C}\right)$ (Figura 3$)$. 


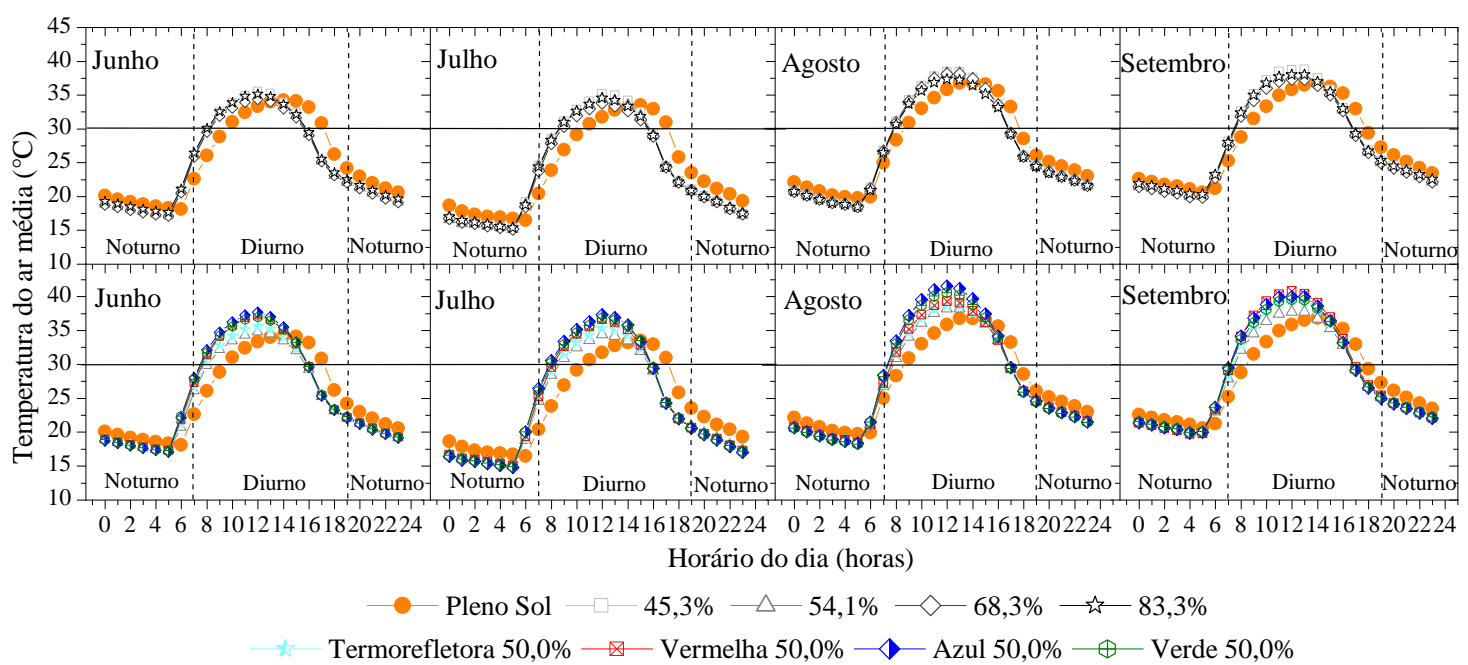

Figura 3: Evolução diurna média mensal da temperatura do ar, no interior de viveiros florestais suspensos com diferentes telas de sombreamento, entre 04/06 a 07/10/2017 (0 e 125 DAT), em Sinop-MT.

A partir das regressões entre temperatura máxima e mínima observadas ao longo do experimento com a área foliar das mudas de Dipteryx alata em níveis crescentes de sombreamento e espectrais da radiação solar, obteve-se temperatura basal superior (TB) de $39,8^{\circ} \mathrm{C}$ e temperatura basal inferior (Tb) de $10,1^{\circ} \mathrm{C}$ (Figuras $4 \mathrm{~A}$ e $4 \mathrm{~B}$ ). Houve influência do microclima dentro das telas de sombreamento sobre o acúmulo de energia térmica pelas mudas aos 125 DAT (Figuras 4C e 4D), visto que a soma térmica acumulada variou em $74,2^{\circ} \mathrm{C}$ entre os níveis quantitativos de sombreamento e $175,89^{\circ} \mathrm{C}$ nas telas coloridas.

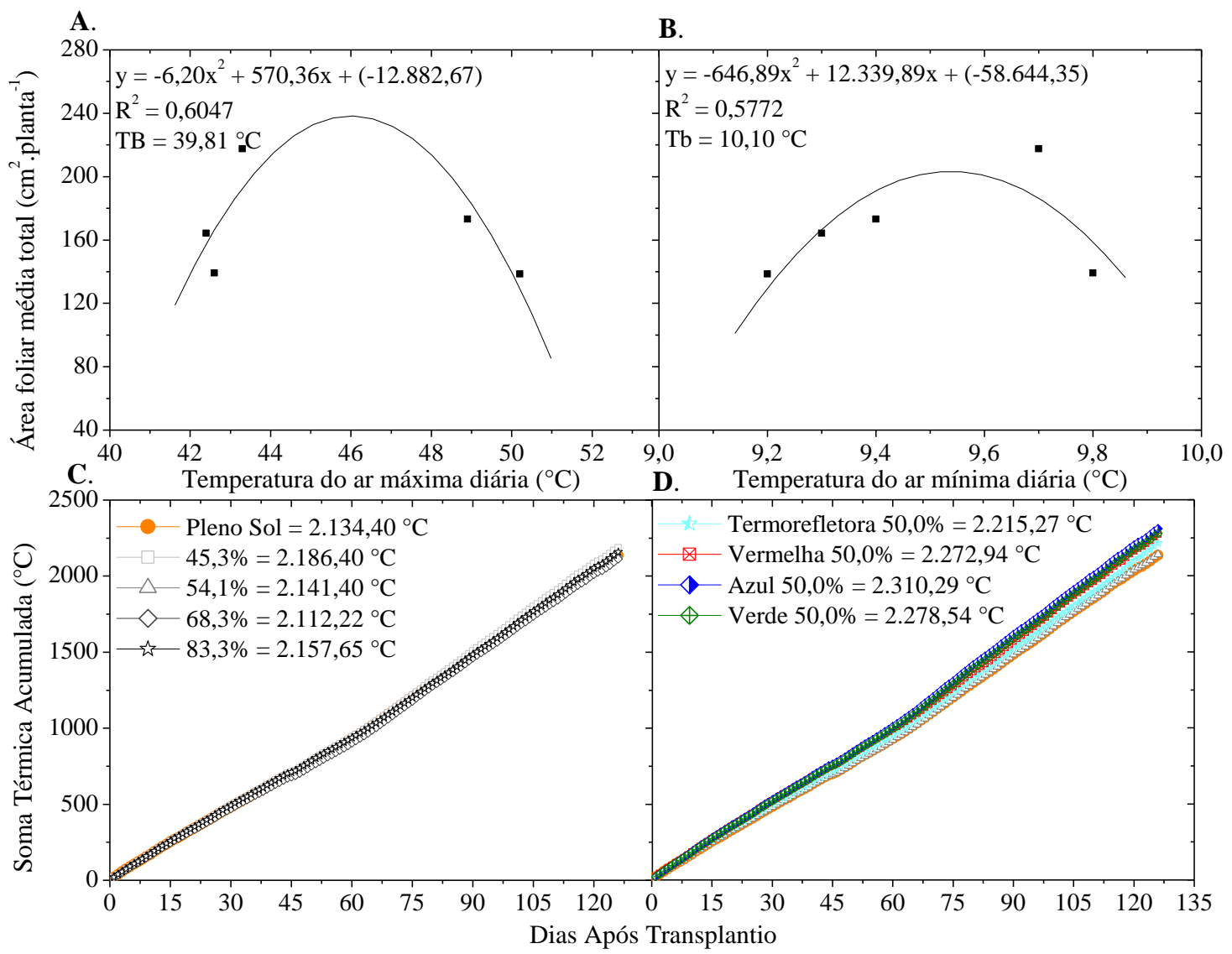

Figura 4: Regressões entre temperatura máxima $(A)$ e mínima $(B)$ com a área foliar, e soma térmica acumulada (C e D) de mudas de Dipteryx alata cultivadas em viveiros florestais suspensos com diferentes telas de sombreamento, entre 04/06 a 07/10/2017 (125 DAT), em Sinop-MT. Fonte: Autores. 
$\mathrm{Na}$ mesma região desse estudo (transição Amazônia-Cerrado), para mudas florestais de Adenanthera pavonina, Cassia fistula, Hymenolobium petraeum e Parkia pendula, submetidas a níveis de sombreamento artificial $(0 ; 50,0$ e $65,0 \%)$, no período seco, as temperaturas basais superiores estimadas foram de 39,$7 ; 37,1 ; 38,6$ e $40,1^{\circ} \mathrm{C}$, temperaturas basais inferiores foram de 15,$0 ; 16,4 ; 14,5$ e $14,6^{\circ} \mathrm{C}$ e as somas térmicas acumuladas foram de 682,$15 ; 584,96 ; 715,14$ e $707,31^{\circ} \mathrm{C} \cdot \mathrm{dia}^{-1}$ (aproximadamente $30 \mathrm{DAT}$ ), respectivamente [9].

As maiores amplitudes térmicas observadas especialmente na tela azul tanto na estação seca (Figura 2) quanto ao longo do dia (Figura 3) no período de produção das mudas permitiram a redução no diâmetro do coleto, no número de folhas e de folíolos (Figura 5 e Tabela 2), e consequentemente na área foliar (Figura 6D) das mudas de Dipteryx alata. As altas temperaturas que podem desativar a enzima Rubisco e associadas ao bloqueio em 50\% do comprimento de onda azul que estimulam a redução da abertura estomática comprometem a fixação de $\mathrm{CO}_{2} \mathrm{e}$ consequentemente a fotossíntese líquida da planta, causando uma redução no acúmulo de biomassa [20] refletindo no crescimento das mudas pelo observado nesse estudo. 

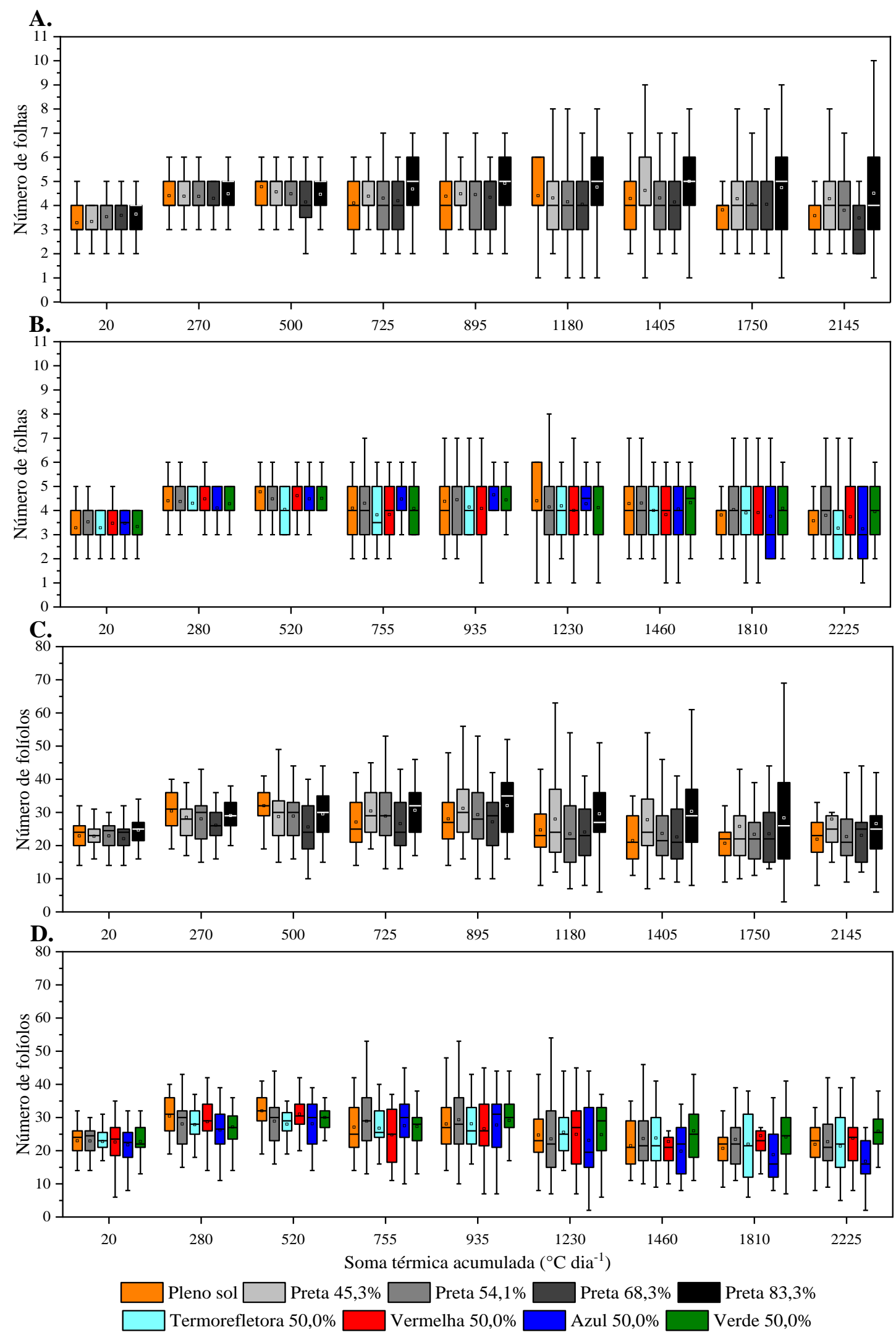

Figura 5: Boxplot do número de folhas e de foliolos por muda da espécie Dipteryx alata cultivadas em viveiros florestais suspensos com diferentes telas de sombreamento, entre 04/06 a 07/10/2017 (125 DAT), em Sinop-MT. Em que: I intervalo interquartil (amplitude entre o quartil superior e inferior); $\square$ média; - 
Tabela 2: Parâmetros morfométricos do crescimento de mudas de Dipteryx alata cultivadas em viveiros florestais suspensos com diferentes telas de sombreamento, aos 125 DAT, em Sinop-MT.

\begin{tabular}{|c|c|c|c|c|}
\hline \multicolumn{5}{|c|}{ Telas pretas (níveis quantitativos de radiação global) } \\
\hline Telas & $\begin{array}{l}\text { Altura } \\
(\mathrm{cm})\end{array}$ & Diâmetro (mm) & $\mathrm{N}^{\circ}$ de Folhas & $\begin{array}{c}\quad \mathrm{N}^{\circ} \mathrm{de} \\
\text { Folíolos }\end{array}$ \\
\hline Pleno Sol & $13,53 \mathrm{a}$ & $5,33 \mathrm{a}$ & $3,57 \mathrm{a}$ & $21,90 \mathrm{a}$ \\
\hline Preta $45,3 \%$ & $13,34 \mathrm{a}$ & $5,34 \mathrm{a}$ & $4,28 \mathrm{a}$ & $28,00 \mathrm{a}$ \\
\hline Preta $54,1 \%$ & $13,12 \mathrm{a}$ & $5,12 \mathrm{ab}$ & $3,80 \mathrm{a}$ & $22,72 \mathrm{a}$ \\
\hline Preta $68,3 \%$ & $12,20 \mathrm{a}$ & $4,69 \mathrm{~b}$ & $3,48 \mathrm{a}$ & $23,05 \mathrm{a}$ \\
\hline Preta $83,3 \%$ & $13,58 \mathrm{a}$ & $4,95 \mathrm{ab}$ & $4,50 \mathrm{a}$ & $26,64 \mathrm{a}$ \\
\hline Média & 13,17 & 5,1 & 3,95 & 24,66 \\
\hline DMS & 1,98 & 0,6 & 1,39 & 8,98 \\
\hline \multicolumn{5}{|c|}{ Telas coloridas (níveis espectrais da radiação solar) } \\
\hline Telas & $\begin{array}{l}\text { Altura } \\
(\mathrm{cm})\end{array}$ & Diâmetro (mm) & $\mathrm{N}^{\circ}$ de Folhas & $\begin{array}{l}\quad \mathrm{N}^{\circ} \mathrm{de} \\
\text { Folíolos }\end{array}$ \\
\hline Pleno Sol & $13,53 \mathrm{a}$ & $5,33 \mathrm{a}$ & $3,57 \mathrm{a}$ & $21,90 \mathrm{ab}$ \\
\hline Preta $50,0 \%$ & $13,12 \mathrm{a}$ & $5,12 \mathrm{a}$ & $3,80 \mathrm{a}$ & $22,72 \mathrm{ab}$ \\
\hline Termorefletora $50,0 \%$ & $12,44 \mathrm{a}$ & $5,09 \mathrm{ab}$ & $3,26 \mathrm{a}$ & $21,37 \mathrm{ab}$ \\
\hline Vermelha $50,0 \%$ & $13,09 \mathrm{a}$ & $5,09 \mathrm{ab}$ & $3,74 \mathrm{a}$ & $23,78 \mathrm{ab}$ \\
\hline Azul 50,0\% & $12,15 \mathrm{a}$ & $4,52 \mathrm{~b}$ & $3,25 \mathrm{a}$ & $16,76 \mathrm{~b}$ \\
\hline Verde $50,0 \%$ & $13,44 \mathrm{a}$ & $5,14 \mathrm{a}$ & $3,95 \mathrm{a}$ & $25,85 \mathrm{a}$ \\
\hline Média & 13 & 5,07 & 3,62 & 22,26 \\
\hline DMS & 2,28 & 0,59 & 1,27 & 7,49 \\
\hline
\end{tabular}

Os valores obtidos para Dipteryx alata corroboram com as observações para mudas nativas da Amazônia [9] e para mudas de eucalipto das espécies Corymbia citriodora e Eucalyptus urophylla produzidas em diferentes condições ambientais entre 2014 e 2015 em Itajubá-MG [10], onde observou-se temperaturas basais inferior e superior de 8,7 e $41,3^{\circ} \mathrm{C}$; e 11,5 e $40,5^{\circ} \mathrm{C}$, respectivamente. Resultados semelhantes também foram observados em mudas de Eucalyptus grandis e Eucalyptus saligna produzidas em campo no município de Santa Maria-RS [21], entre maio e outubro de 2005 , cujas temperaturas basal inferior foram de 10,0 e $8,0^{\circ} \mathrm{C}$; e ainda para cultivares de oliveira Arbequina e MGS ASC315, que apresentaram estimativas de Tb iguais a 10,5 e $11,0^{\circ} \mathrm{C}$, respectivamente [8].

Nas diferentes condições de sombreamento as mudas de Dipteryx alata apresentaram variações no número de folhas e de folíolos ao longo de 125 DAT. Aos 0 DAT (após a fase de aclimatação) representado pela soma térmica acumulada em cada microambiente, as mudas apresentavam médias de 3,43 folhas e 22, 46 folíolos, enquanto que aos 125 DAT, nas telas pretas o número de folhas e de folíolos variaram de 3,48 a 4,50 e 22,72 a 28,00 (Figura 5A e 5C) e nas telas coloridas variaram de 3,25 a 3,95 e 16,76 a 25,85 (Figuras 5B e 5D), não diferindo entre si (Tabela 2).

O surgimento e a expansão de folhas ocorrem a partir de divisões e expansões celulares, respectivamente, processos dependentes da energia provida pela incidência da radiação solar. As folhas são formadas a partir de células iniciais [22], dentro do meristema por meio de marcadores de iniciação foliar, dependentes da regulação negativa dos genes KNOX, que junto com outros processos citogenéticos induzem a sinalização de hormônios vegetais, como citocinina e auxina, que são responsáveis por manter as funções de manutenção do meristema apical do caule e por redirecionar o crescimento desse meristema para a iniciação das folhas; do contrário, na ausência da luz a ontogenia foliar é interrompida [23].

As flutuações no número de folíolos foram mais perceptíveis que no número de folhas das mudas de Dipteryx alata durante o período avaliado (Figura 5), isso porque, uma folha da muda dessa espécie pode ter entre 8 a 10 folíolos, consequentemente, quando houve renovação das folhas o número de folíolos ficou reduzido até a expansão da nova folha que levou cerca de 10 dias.

As variações do número de folhas nas plantas também são dependentes do processo de senescência e abscisão foliar, por meio do qual ocorre a manutenção do aparelho fotossintético das plantas (renovação foliar) influenciadas pela idade fisiológica da folha ou por algum tipo de estresse ambiental, como o estresse térmico, que pode gerar mudanças nos níveis dos hormônios sinalizadores: ácido abscísico [24] e etileno [25]. Dessa forma, o aumento significativo da 
temperatura do ar diurna, acima da temperatura basal superior da planta [26], especialmente nos meses de agosto e setembro, pode ter desacelerado o surgimento e expansão de folhas das mudas de Dipteryx alata (Figuras 3 e 5), todavia nota-se um menor efeito com o aumento do nível de sombreamento.

A partir dos polinômios ajustados para o número de folhas e de folíolos com base na soma térmica acumulada para todas as telas de sombreamento, obteve-se os valores médios de filocrono para as mudas de Dipteryx alata de $191,04^{\circ} \mathrm{C}$ dia $^{-1}$.folha ${ }^{-1}$ e $21,90^{\circ} \mathrm{C} \cdot$ dia $^{-1}$.folíolo ${ }^{-1}$. Apesar da semelhança no número de folhas e de folíolos das mudas de Dipteryx alata nos tratamentos (Tabela 2) nos níveis crescentes de sombreamento, mudas produzidas na tela poliefina preta com $83,3 \%$ de sombreamento e na condição de pleno sol apresentaram os maiores e menores valores de filocrono

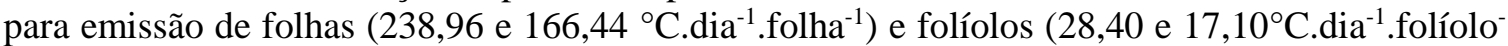
${ }^{1}$ ), respectivamente (Figura 6). Esse comportamento justifica-se pelas diferenças na incidência da radiação global nesses dois ambientes (Tabela 1 e Figura 1A), que podem ter condicionado amplitudes térmicas (calor sensível) maiores na tela poliefina preta com 83,3\% de sombreamento quando comparado com a condição de pleno sol (Figuras 2 e 3 ).

Nos níveis espectrais da radiação solar, maiores valores de filocrono para o surgimento de folhas ocorreu em mudas produzidas na tela termorefletora com $229,07^{\circ} \mathrm{C}_{\text {.dia }}{ }^{-1}$. folha ${ }^{-1}$ e de folíolos na tela verde com $23,08^{\circ} \mathrm{C} \cdot \mathrm{dia}^{-1}$.folíolo ${ }^{-1}$ (Figura 6), enquanto que a tela vermelha apresentou menor valor de filocrono para emissão de folha $147,90^{\circ} \mathrm{C}$ dia $^{-1}$. folha ${ }^{-1}$ e de folíolo $20,39^{\circ} \mathrm{C}_{\text {.dia }}{ }^{-1}$.folíolo ${ }^{-1}$ (Figura 6).

Este resultado indica que, a redução da incidência quanti-qualitativa da radiação solar apresentado na Tabela 1, perfazem na necessidade de maior acúmulo de energia térmica para a emissão de folhas e folíolos, além do fato de a planta emitir maior número de folhas, e consequentemente, ter aumento da área foliar, permitindo maior área de captação da energia radiante para compensação durante o processo fotossintético.

Exemplos desse contexto, podem ser descritos quanto ao crescimento inicial de eucalipto em temperatura do ar variando de 3,8 a $35,5^{\circ} \mathrm{C}$, visto que a espécie Eucalyptus urophylla necessitou de menor acúmulo de energia térmica $\left(46,03^{\circ} \mathrm{C} \cdot \mathrm{dia}^{-1}\right.$.folha $\left.{ }^{-1}\right)$ quando comparada com Corymbia citriodora $\left(62,95^{\circ} \mathrm{C}\right.$.dia ${ }^{-1}$.folha $\left.{ }^{-1}\right)$ [10]. Já para mudas florestais nativas da Amazônia, com cerca de 60 dias, o filocrono variou de 11,$40 ; 19,54 ; 26,72$ e $30,30^{\circ} \mathrm{C}_{\text {dia }}{ }^{-1}$.folha ${ }^{-1}$ para Adenanthera pavonina, Cassia fistula, Hymenolobiuim petraeum e Parkia pendula, respectivamente [9]. Valores próximos também foram observados para cultivares de oliveira Arbequina, que demandaram

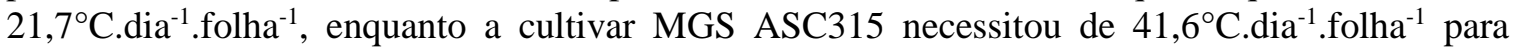
emissão de uma folha [8]. Nesse caso, destaca-se que as exigências térmicas dessas espécies são distintas, pois dependem das características genéticas, adaptações morfofisiológicas e estágio de desenvolvimento vegetativo e reprodutivo do vegetal, bem como, das condições micrometeorológicas e edáficas do local $[8,9]$. 
A.
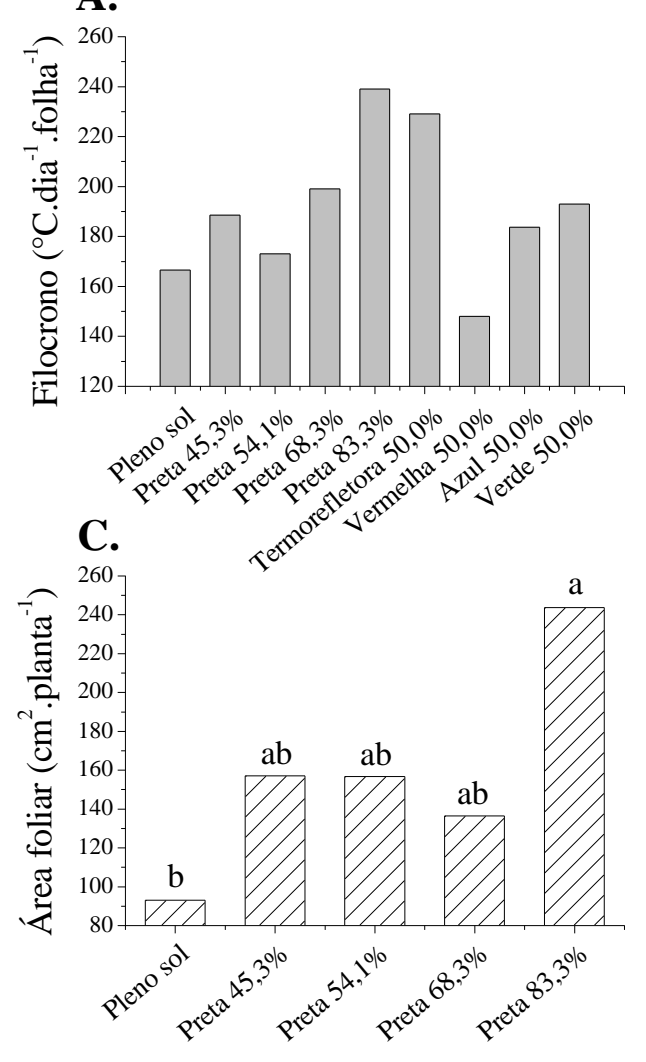

\section{B.}

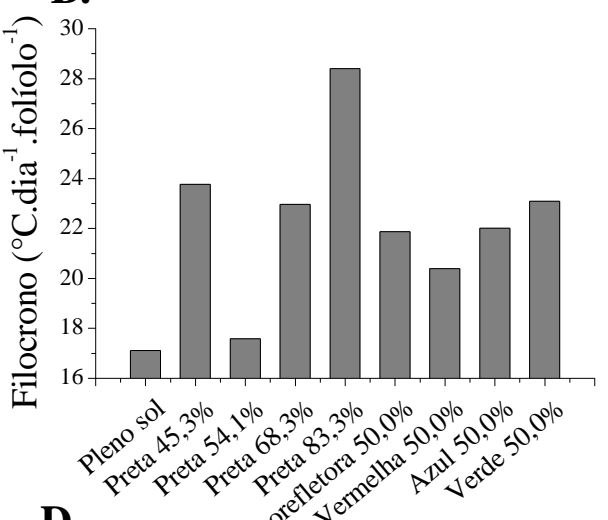

D.

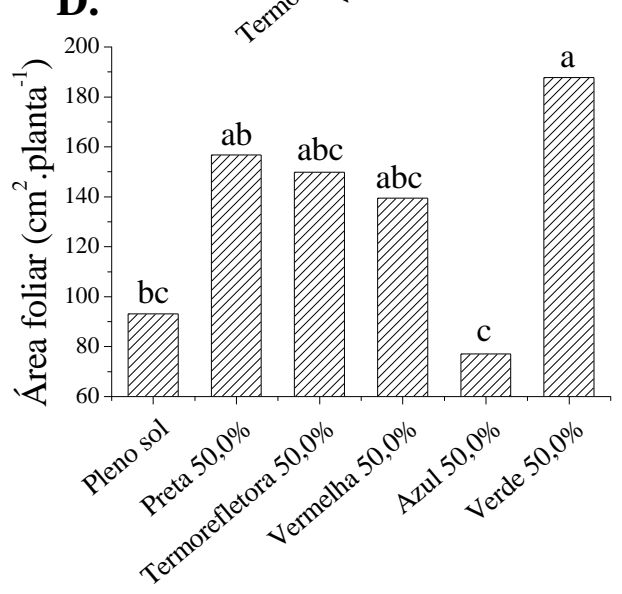

Níveis de sombreamento $(\%)$

Figura 6: Filocrono para o número médio de folhas (A), de foliolos (B) e área foliar (C e D) de mudas de Dipteryx alata, cultivada em viveiros florestais suspensos com diferentes telas de sombreamento, entre 04/06 a 07/10/2017 (125 DAT), em Sinop-MT. Fonte: Autores.

A influência dos fatores genéticos e ambientais também foram verificados em estudos sobre requerimentos térmicos de Cucurbita moschata em diferentes estágios fenológicos na região de transição Cerrado-Amazônia Matogrossense [27] na fenologia e filocrono de duas cultivares de morango cultivados em substratos orgânicos (Albion e Camarosa) em região subtropical do Brasil [28] e na influência da temperatura do ar e do fotoperíodo na taxa de emissão de folhas dos cereais Triticum durum, Triticum aestivum e Hordeum vulgare em ambiente mediterrâneo na Sicília-Itália [29].

Comparando as telas coloridas, que propiciariam maior efeito das radiações espectrais no total incidente de radiação fotossinteticamente ativa (PAR), notou-se que as mudas de Dipteryx alata cultivadas sob tela com bloqueio em 50,0\% do comprimento de onda azul apresentaram efeitos negativos, pois houve aumento da necessidade de acúmulo de energia térmica para produção de área foliar quando comparado com a tela de sombreamento vermelho, que permitiu menor valor de filocrono e aumento da área foliar (Figura 6). Assim, fica evidente que a quantidade, qualidade, duração e densidade de fluxo da radiação solar, interferem no processo da fotossíntese, na produção de pigmentos fotoprotetores e fotossintéticos, surgimento e expansão de folhas [30], transpiração [12], morfologia, anatomia e fotoperiodismo [26].

A área foliar define a quantidade de radiação PAR que a planta pode capturar para produção de fotoassimilados, e possivelmente determina o quanto de biomassa pode ser acumulada [31]. A inibição da incidência do comprimento de onda azul compromete o desenvolvimento do aparelho fotossintetizante como o surgimento e expansão das folhas, produção de pigmentos fotossintéticos, acúmulo de biomassa, característica anatômica e morfológicas, e consequentemente as taxas fotossintéticas da planta [20]. 
Durante o período experimental, sobretudo entre os meses de julho a outubro, ocorreram temperaturas máximas e mínimas superiores e inferiores às temperaturas basais da espécie Dipteryx alata em todas as condições de sombreamento, especialmente sob as telas coloridas (Figura 2). A dinâmica da temperatura do ar nas telas de sombreamento em níveis crescentes e espectrais da radiação solar, é dependente do balanço de radiação que ocorre dentro destes microambientes, sendo indicativos de seletividade de comprimentos de onda transmitidos por cada tela, deste modo, o microclima condicionado em cada tratamento influenciou para obtenção de diferentes valores de filocrono das mudas de Dipteryx alata.

As condições ambientais exercem papel importante no estabelecimento inicial das plantas, pois as interações de fatores ambientais como radiação solar, temperatura do ar e umidade relativa do ar influenciam significativamente nas respostas das plantas à mudança de temperatura, acelerando ou prolongando as fases fenológicas de desenvolvimento [32], a taxa de emissão de folhas e a área foliar [7] e em condição de estresse térmico, de modo a comprometer a qualidade de produção do vegetal [11]. Nesse estudo, foram identificadas algumas adaptações do aparelho fotossintético das mudas de Dipteryx alata na condição de pleno sol, como: redução do número de folhas e consequentemente da área foliar, limbo foliar (folíolos) mais espesso e inclinação das folhas no sentido paralelo à incidência da radiação solar em função da alta temperatura e incidência da radiação global. Essas adaptações demonstram a capacidade da espécie em se regular fisiologicamente em função do seu ambiente de cultivo.

Não podemos afirmar bioquimicamente que as temperaturas máximas e mínimas acima e abaixo das temperaturas basais prejudicaram os componentes celulares e processos fisiológicos das mudas de Dipteryx alata, uma vez que, não foram realizadas análises bioquímicas destas plantas nos diferentes tratamentos para comprovar tal fenômeno. Contudo, sabe-se que toda alteração ambiental desfavorável para as plantas e pelas respostas morfométricas evidenciadas, como a redução no crescimento das mudas e na expansão foliar (Figuras 5-6 e Tabela 2), sobretudo na tela azul, observadas neste estudo, estimula mecanismos de defesa para adaptações morfofisiológicas das plantas, que por sua vez, são capazes de conter possíveis prejuízos significativos que esse tipo de estresse abiótico pode causar para as plantas em geral.

Os componentes celulares destes organismos funcionam como termosensores, na percepção de mudanças de temperatura e sinalização de moléculas enzimáticas e proteicas da membrana plasmática ou do núcleo celular, resultando em interações metabólicas e hormonais que interferem no crescimento e desenvolvimento da planta. Ademais, as plantas possuem proteínas capazes de recuperar seus processos fisiológicos através da sinalização a nível celular de proteínas térmicas e reativar enzimas desnaturadas pela alta temperatura, levando a uma termoresistência do vegetal que pode ser diferente em cada estádio de desenvolvimento [32], o que de fato parece ter ocorrido com as mudas da espécie Dipteryx alata nos diferentes microambientes, porém sem prejuízos significativos no crescimento das mudas.

As proteínas de choque térmico (HSPs) se acumulam rapidamente em compartimentos celulares, sendo expressas em tecidos das folhas e raízes da planta sob estresse térmico. Essas proteínas são reguladas por genes de fator de transcrição (HSFs), os quais desempenham funções metabólicas diante de um tipo de estresse ambiental. O fator de choque térmico (HSFA6b) sobre a resposta ao estresse térmico da espécie Arabidopsis thaliana demonstrou ter uma forte conecção à sinalização do fito-hormônio ácido abscísico (ABA) na termotolerância adquirida dessa espécie, esse fator de transcrição HSFA6b, cuja expressão depende do sinal ABA é necessário para resistência ao estresse térmico mediada por ABA [24].

Estudo mais recente com Arabidopsis thaliana revelou a sinalização e um aumento expressivo nos níveis do hormônio vegetal ácido jasmônico (JA) como resposta à alta luminosidade, estresse térmico e a combinação de ambos. A combinação de luz e calor excessivo causou danos irreversíveis na atividade do fotossistema II (PSII); alterações estruturais e metabólicas dos cloroplastos, como a redução no número de tilacóides, aumento no número e no percentual de danos dos grânulos de amido por cloroplasto [33], essas alterações comprometem a produção de clorofila, causando a despigmentação das folhas e consequentemente redução na atividade fotossintética. Também foi observado abertura estomática induzida, diminuição do teor relativo de água e aumento na temperatura das folhas, cuja a capacidade de reparo do PSII ficou reduzida, comprometendo a 
capacidade fotossintética e de sobrevivência da planta exposta a essa combinação de estresse abiótico [33].

A planta, quando exposta às altas temperaturas, regula o fluxo de saída de água pela folha através do fechamento dos estômatos, e a água que se encontra no corpo do vegetal é redirecionada para a termorregulação da temperatura foliar sob o calor excessivo. Dessa forma, o crescimento e desenvolvimento da planta pode ser afetado, já que há redução da assimilação de dióxido de carbono pelos estômatos e, consequentemente, redução na produção de fotoassimilados durante o processo fotossintético.

\section{CONCLUSÃO}

Níveis crescentes de sombreamento e níveis espectrais de radiação solar influenciam no acúmulo de energia térmica, no surgimento e expansão foliar de mudas de Dipteryx alata.

O surgimento e expansão de folhas de mudas de Dipteryx alata é dependente da dinâmica microclimática gerada pelas variações da quantidade e qualidade de radiação solar incidente em ambientes protegidos, contudo a espécie apresenta forte adaptabilidade a diferentes condições ambientais.

Para aumentar a área foliar e consequentemente a atividade fotossintética da planta, recomendase a produção das mudas sob sombreamento, exceto sob a tela azul.

\section{REFERÊNCIAS BIBLIOGRÁFICAS}

1. Lorenzi H. Árvores Brasileiras: manual de identificação e cultivo de plantas arbóreas nativas do Brasil. 5. ed. Nova Odessa: Instituto Plantarum, 2008. 368 p.

2. Canuto DS de O, Zaruma D UG, de Moraes MA; da Silva AM, de Moraes MLT, Freitas MLM. Caracterização genética de um teste de progênies de Dipteryx alata Vog. proveniente de remanescente florestal da Estação Ecológica de Paulo de Faria, SP, Brasil. Hoehnea. 2015;42(4):641-648, doi: doi: 10.1590/2236-8906-13/RAD/2015

3. da Cruz KS, da Silva MA, de Freitas O, Nevesa VA. Partial characterization of proteins from baru (Dipteryx alata Vog) seeds. J Sci Food Agric. 2011;91(11):2006-2012, doi: 10.1002/jsfa.4410

4. Siqueira EM de A, Marin AMF, da Cunha M de SB, Fustinoni AM, de Sant'ana, LP, Arruda SF. Consumption of baru seeds [Dipteryx alata Vog.], a Brazilian savanna nut, prevents iron-induced oxidative stress in rats. Food Res Int. 2012;45(1):427-43, doi: 10.1016/j.foodres.2011.11.005

5. Mota LH de S, Scalon S de PQ, Heinz R. Sombreamento na emergência de plântulas e no crescimento inicial de Dipteryx alata Vog. Ci Florestal. 2012;22(3):423-431.

6. Wu A, Hammer GL, Doherty A, Caemmerer S, Farquhar GD. Quantifying impacts of enhancing photosynthesis on crop yield. Nature Pl. 2019;5:380-388, doi: 10.1038/s41477-019-0398-8

7. Streck NA, Uhlmann LO, Zanon AJ, Bisognin DA. Impact of elevated temperature scenarios on potato leaf development. Eng Agríc. 2012;32(4):689-697. doi: 10.1590/S0100-69162012000400008

8. Martins FB, Reis D da F, Pinheiro MVM. Temperatura base e filocrono em duas cultivares de oliveira. Ci Rural. 2012; 42(11):1975-1981.

9. Monteiro EB, da Silva CC, da Silva AC, de Souza AP. Estimating Emission of Leaves Seedlings Forest in Different Shading Levels, at Conditions of Transition Amazon-Cerrado, Brazil. Amer J Plant Sci. 2014; 5: 2330-2341, doi: 10.4236/ajps.2014.515247.

10. de Freitas CH, Martins FB, Abreu MC. Cardinal temperatures for the leaf development of Corymbia citriodora and Eucalyptus urophylla seedlings. Pesq Agropec Bras. 2017;52(5):283-292, doi: 10.1590/S0100-204X2017000500001.

11. Hatfield JL, Prueger JH. Temperature extremes: Effect on plant growth and development. Weather Clim Extremes. 2015;10:4-10, doi:10.1016/j.wace.2015.08.001.

12. Marenco RA, Camargo MAB, Antezana-Vera SA, Oliveira MF. Leaf plasticity in six forest tree species of central Amazonia. Photosynthetica. 2017;55(4):679-688, doi: 10.1007/s11099-017-0703-6.

13. de Souza AP, da Mota LL, Zamadei T, Martim CC, de Almeida FT, Paulino J. Classificação climática e balanço hídrico climatológico no estado de Mato Grosso. Nativa. 2013;1(1):34-43.

14. Martim CC, Zmadei T, de Souza AP, de Almeida FT, Zolin CA. Coeficientes de Angstrom-Prescott e a evapotranspiração de referência na transição Cerrado-Amazônia do Mato Grosso. Ver Bras Climatol. 2020;26:579-594, doi: 105380/abclima.v26i0

15. Melhem TS. Fisiologia da germinação das sementes de Dipteryx alata Vog. (Leguminosae- Lotoideae). Hoehnea. 1975;5:59-90. 
16. Corrêa GC, dos Santos MM, Artiaga SRAR. Influência do período de armazenamento de frutos na germinação de sementes de baru (Dipteryx alata Vogel). Agr Academy. 2017;4(7):297-305.

17. Pereira AR, Sedyiama GC, Villa Nova NA. Evapotranspiração. Campinas: FUNDAG, 2013. 323 p.

18. de Souza AP, Ramos CMC, de Lima AD, Florentino H de O, Escobedo JF. Comparison of methodologies for degree-day estimation using numerical methods. Acta Scientiarun Agron. 2011;33(3):391-400, doi: doi: 10.4025/actasciagron.v33i3.6018.

19. de Souza AP, Zamadei T, Monteiro EB, Casavecchia BH. Transmissividade Atmosférica da Radiação Global na Região Amazônica de Mato Grosso. Rev Bras Meteorol. 2016;31(4):639-648, doi:10.1590/0102-7786312314b20150147.

20. Wang XY, Xu XM, Cui J. The importance of blue light for leaf area expansion, development of photosynthetic apparatus, and chloroplast ultrastructure of Cucumis sativus grown under weak light. Photosynthetica. 2015;53(2):213-222.

21. Martins FB, da Silva JC, Streck NA. Estimativa da temperatura-base para emissão de folhas e do filocrono em duas espécies de eucalipto na fase de muda. Rev Árvore. 2007;31(3):373-381.

22. Moon J, Hake S. How a leaf gets its shape. Curr Opin Plant Biol. 2011;14:24-30, doi: 10.1016/j.pbi.2010.08.012.

23. Byrne ME. Making leaves. Curr Opin Plant Biol. 2012;15:24-30, doi: 10.1016/j.pbi.2011.10.009.

24. Huang Y, Niu C, Yang C, Jinn T. The Heat Stress Factor HSFA6b Connects ABA Signaling and ABAMediated Heat Responses. Plant Physiol. 2016;172:1182-1199, doi: 10.1104/pp.16.00860.

25. Ceusters J, Poel B. V. Ethylene Exerts Species-Specific and Age-Dependent Control of Photosynthesis. Plant Physiol. 2018;176(4):2601-2612, doi: 10.1104/pp.17.01706.

26. Harmer, SL. The Circadian System in Higher Plants. Ann Revi Plant Biol. 2009;60: 357-377, doi: 10.1146/annurev.arplant.043008.092054.

27. de Souza AP, da Silva AC, Pizzatto M, de Souza ME. Thermal Requirements and Productivity of Squash (Cucurbita moschata Duch.) in the Cerrado-Amazon Transition. Agroci Uruguay. 2017;21(2):15-22.

28. Diel MI, Pinheiro MVM, Cocco C, Fontana DC, Caron BO, de Paula GM, Pretto MM, Thiesen LA, Schmidt D. Phyllochron and phenology of strawberry cultivars from different origins cultivated in organic substracts. Sci Horticulturae. 2017;220:226-232, doi: org/10.1016/j.scienta.2017.03.053.

29. Riggi E, Scordia D, Cuzzola CF, Testa G, Cosentino SL. Leaf appearance rate and final main stem leaf number as affected by temperature and photoperiod in cereals grown in Mediterranean environment. Italian J Agron. 2017;12(770):183-191, doi: 10.4081/ija.2017.770.

30. Zhang SB, Zhang JL. Variations in light energy dissipation in Woodfordia fruticosa leaves during expansion. Photosynthetica. 2017;55(4):705-715, doi: 10.1007/s11099-017-0692-5.

31. Manandhar A. Sinclair TR, Rufty TW, Ghanem ME. Leaf emergence (phyllochron index) and leaf expansion response to soil drying in cowpea genotypes. Physiol Plantarum. 2017;160:201-208, doi: 10.1111/ppl.12544.

32. Bahuguna RN, Jagadish KSV. Temperature regulation of plant phenological development. Environm Experim Bot. 2015;111:83-90, doi: 10.1016/j.envexpbot.2014.10.007.

33. Balfagón D, Sengupta S, Gómez-Cadenas A, Fritschi FB, Azad RK, Mittler R, Zandalinas SI. Jasmonic Acid Is Required for Plant Acclimation to a Combination of High Light and Heat Stress. Plant Physiol. 2019;181(4):1668-1682, doi: 10.1104/pp.19.00956 